\title{
Expression Profiling of Resistance Gene Analogs from French Bean (Phaseolus vulgaris L.) for the Manifestation of Moong Bean Yellow Mosaic Virus
}

\author{
B. Divya*, B. Fakrudin and C. Ashwat \\ College of Horticulture, Bengaluru, University of Horticulutural Sciences, Bagalkot \\ Indian Institute of Horticultural Sciences, Hesarghatta, Bengaluru, India \\ *Corresponding author
}

\begin{abstract}
A B S T R A C T
\section{Keywords}

French bean, RGAs,

Arka Anoop,

MYMV and

Expression analysis

Article Info

Accepted:

07 February 2019

Available Online:

10 March 2019

The popular and susceptible french bean genotype Arka Anoop was used for expression profiling of RGAs for the manifestation of $M Y M V$. Leaf tissue was collected from both disease free and artificially disease challenged plants at $7^{\text {th }}, 15^{\text {th }}$ and $30^{\text {th }}$ DAI and syntesized cDNA. The expression level of selected 10 RGA genes of french bean was measured in both disease free and artificially inoculated leaf tissues separately at $7^{\text {th }}, 15^{\text {th }}$ and $30^{\text {th }}$ DAI. 10 RGA genes were tested under $M Y M V$ infested condition in french bean. All 10 selected RGA genes were expressed in leaf tissues at different days after inoculation with $M Y M V$. COHFBRGA-2, 6, 8 and 10 genes of french bean were upregulated in leaf of susceptible genotypes at disease inoculation condition at all the intervals. COHFBRGA-3, 4, 5 and 7 was down- regulated among all the intervals of disease development compared to control. Whereas, COHFBRGA-9 expressed only at 30 DAI.
\end{abstract}

\section{Introduction}

French bean, Phaseolus vulgaris L. $(2 \mathrm{n}=22)$ is a member of the family Fabaceae. It is an important legume vegetable grown for its tender green pods either for fresh consumption or for processing as canned, frozen or freeze dried product. It is a nutritive vegetable which supplies protein $(1.8 \mathrm{~g})$, calcium $(132 \mathrm{mg})$, thiamin $(0.08 \mathrm{mg})$, riboflavin $(0.06 \mathrm{mg})$ and vitamin $\mathrm{C}(24 \mathrm{mg})$ per $100 \mathrm{~g}$ of edible pods. Its pods can be used to strengthen diuretic, flushing of toxins from the body and also infused in the treatment of diabetics (Prajapati, 2003).

It is native of new world, principally Central and South America (Kalpan, 1981) with small genome $633 \mathrm{Mbp}$ (Arumuganatham and Earle, 1991). It is originated from wild species Phaseolus aborigineus L. and domesticated in Mexico, Peru and Colombia about 8000 years ago. In world, french bean is grown over an area of 1.48 million ha with annual production of 17.65 million MT and the productivity of $11.95 \mathrm{t} / \mathrm{ha}$. In India, its cultivation is in 0.21 
million ha with production of 0.58 million MT and productivity of $2.8 \mathrm{t} / \mathrm{ha}$ (Anon., 2015).

Like any other crops, legume vegetables are also susceptible to various biotic and abiotic stresses. Among the biotic stresses, Moong Bean yellow mosaic virus (MYMV) has become epidemic in bean growing areas and especially in locations where humid to moderately humid conditions, long dew periods and cool conditions prevail during the growing season of beans. It spreads through white flies (Rangaswamy, 1975). The Virus infects leaves, pods, petioles, rarely stems and branches. Initial symptoms appear usually on yellowing mosaic discoloration, followed by defoliation (Harter and Zaumeyer, 1941).

The yield loss due to MYMV ranges from 18 to 98 per cent (Mohan et al., 1993). This disease is more severe in tropics than in temperate region (Coyne and Schuster, 1975). But, genetic resistance always has an edge over the other means of disease control as it is eco-friendly. Host plant resistance is very important because of high virulence and diversity of pathogen (Lopez et al., 2003).

Many defense responses are initiated by resistance gene/genes, providing a mechanism by which the plant can recognize a pathogen and execute a defense response against it. Plant resistance $(\mathrm{R})$ genes are thought to be one of the components of the genetic resistance mechanism in plants (Flor, 1956). Development of plant organs is determined by differential gene expression which can be regulated at different levels. Numerous $R$ genes and RGAs have now been cloned, determination of activity and specificity against a given pathogen for development of durable resistance is important in french bean and other crop species (Madsen et al., 2003). Advancement in technologies such as DNA sequencing methodologies, throughput platform DNA array, northern blotting, subtractive hybridization, real-time PCR etc. have tremendously increased our knowledge of transcriptomes. But, the advent of real-time PCR technology has significantly changed the field of measuring gene expression in both the animal and plant molecular biology research.

Real-time PCR is the technique of collecting data throughout the PCR process as it occurs, thus combining amplification and the detection into a single step. It has become one of the most widely used methods of gene quantitation because of its high sensitivity, good reproducibility and wide dynamic quantitation range. It is the most sensitive method for the detection and quantitation of gene expression levels, in particular for low abundant transcripts in tissues with low RNA concentrations, from limited tissue sample and for the elucidation of small changes in mRNA expression levels (Mackay et al., 2002). Keeping these in view, we conducted on expressional analysis of resistance gene analogs in response to rust disease manifestation in French bean.

\section{Materials and Methods}

\section{Disease induction and tissues collection from pot experiment}

French bean genotype Arka Anoop was raised in pots containing a mixture of soil, sand and well decomposed Farm Yard Manure (FYM) in the ratio of $2: 1: 1$. The filled pots were kept in polyhouse. The pot mixture was sterilized before use. In replicated trials one seed was sown in each pot. To collect tissues from MYMV infected plants, the insect (vector) transmission protocol developed by Aidawaati et al., (2002) was used. MYMV transmission experiment with Bamisia tabaci were conducted using rectangular nylon cages with mesh top. Around 50-100 B. tabaci/ plant were introduced into the cage through a hole made. After 24 and $48 \mathrm{~h}$ acquisition access 
period B. tabaci adults were removed from MYMV agro infected french bean plants and transferred to separate cage containing healthy without virus inoculated french bean (Arka Anoop). After $24 \mathrm{~h}$ inoculated access period B. tabaci were removed and tissues were collected targeting different stages of disease manifestation both from challenged and control plants i.e., Arka Anoop plants (7th, 15th and 30th DAI). The tissues were frozen and stored at $-800 \mathrm{C}$ for isolation of total RNA (Plate 1).

\section{RNA isolation and cDNA synthesis}

Total RNA was isolated from leaf tissues of Arka Anoop and Arka Sharath genotypes from both rust infected and non infected conditions using TRIzol reagent and driver cDNAs were prepared from the total RNA of each treatment by using SuperScript ${ }^{\circledR} \quad$ VILO $^{\text {TM }}$ cDNA Synthesis Kit (Cat.no.11754-050, Invitrogen) as per the manufacturer's protocol (Plate 2-4).

\section{Candidate-gene selection and primer design}

For 10 selected sequences of RGAs cloned in the our previous study the primer pairs were designed using Primer3Plus software and primers were synthesized by Eurofins Genomics India Pvt. Ltd. Bengaluru. A predicted melting temperature (Tm) of $60+2{ }^{\circ} \mathrm{C}$, primer lengths of $20-24$ nucleotides, guanine-cytosine (GC) contents of 45-55 per cent and PCR amplicon length of 90-200 base pairs (bp) were adopted for designing the primer pairs. The specificity of primer pairs were reconfirmed by searching homology in NCBI, BLAST search. The list of candidate genes and their respective primer pairs are shown in Table 1. PCR amplification of RGAs was optimized for different components using gradient PCR by Eppendorf master cycles gradient. PCR reactions were performed for genotype in a total volume of $20 \mu \mathrm{l}$ containing $100 \mathrm{ng}$ of cDNA, $1 \times$ PCR buffer, $2.5 \mathrm{mM}$
$\mathrm{MgCl} 2,0.2 \mathrm{mM}$ dNTPs, $0.1 \mu \mathrm{M}$ of each primer, and 2.5 units of Taq polymerase (Invitrogen Life Technologies, Carlsbad, CA). Cycling conditions were initial denaturation at $95^{\circ} \mathrm{C}$ for $10 \mathrm{~min}$, followed by 40 amplification cycles $\left(95^{\circ} \mathrm{C}\right.$ for $15 \mathrm{~s}$, annealing temp ${ }^{\circ} \mathrm{C}$ for $20 \mathrm{~s}$, and $68^{\circ} \mathrm{C}$ for 20s) and a melting curve step at $95^{\circ} \mathrm{C}$ for $10 \mathrm{~min}$ before holding at $\left.4^{\circ} \mathrm{C}\right)$.

The master mix of different components of real-time PCR was prepared fresh to avoid handling errors. The reaction mixture of $10 \mu \mathrm{l}$ containing $1.0 \mathrm{ng}$ cDNA, $200 \mathrm{nM}$ of each gene specific primer and $5 \mu \mathrm{l}$ of $2 \mathrm{x}$ SYBR green reagents (Cat.\#4368706, Ambion, USA) were used in the experiment. Individual components of reaction mixture were standardized for 10 $\mu \mathrm{l}$ reaction volume. In our experiment we selected Arabidopsis thaliana housekeeping gene actin as an internal control (Caldana et al., 2007 and Czechowski et al., 2004).

The mathematical model delta-delta $\mathrm{Ct}$ method (Livak and Schmittgen, 2001) was used to determine relative expression ratio (fold change). In real-time PCR, fluorescence was recorded at each cycle to monitor the generation of amplified product. For proper calculation of initial target levels, differences in efficiency of amplification (E) must be taken into consideration. Even small differences in amplification efficiencies (E) will get added up making large apparent differences in mRNA levels. The absolute quantification requires a set up of standard curves from which PCR efficiency will be deduce; the disadvantages of standard curves are (i) the extra efforts and cost needed to set up additional samples (ii) Non matching $E$ due to presence of inhibitors and serial dilutions. The relative quantification with PCR efficiency correction was adopted to calculate the fold change expression. PCR efficiency of all the RGAs was obtained from the exponential phase of each individual 
amplification plot using the equation $(1+\mathrm{E})$ =10slope (Ramakers et al., 2003). The LinReg PCR (http://www.bioinfo@amc.uva.nl; subject: LinRegPCR) software based on the above equation proposed a linear regression on the log fluorescence per cycle number data as an assumption-free method was used to calculate starting concentrations of mRNA and PCR efficiencies for each sample. The log-linear part of the PCR data was determined for each sample by selecting a lower and an upper limit of a "window of linearity". Linear regression analyses was used to calculate the intercept and the slope, log (No) and $\log$ (eff.) respectively, from the straight line that fits best to the included data points. The individual PCR efficiency follows from the slope of the linear regression line (Eff $=10$ slope) and used as a quality check to exclude possible contained samples. To ensure unambiguous selection of data point within the "window of linearity", the lines consisting of at least 4 and not more than 6 data points with the highest R2 value (0.99) and slope close to the maximum slope were selected.

\section{Processing the raw fluorescence data}

Pre-requisite for LinRegPCR to achieve maximum PCR efficiency is background corrected fluorescence data points of each well. Raw fluorescence data was obtained from the Applied Biosystems stepone RTPCR and this background was due to residual fluorescence of the dye, differences in tube transparency, dust, noise of the electronics etc. In majority of cases, a variable background makes a near-linear contribution to the curves generated by the amplifier and it should be subtracted from the raw fluorescence without distorting the data considerably. For background correction, the baseline fluorescence data was collected from 3-15 cycles. The fluorescence increments (raw fluorescence-Yo) were normalized to reaction fluorescence background (Yo) for each sample reaction as below (Yu et al., 2006).
Normalized fluorescence $=$ raw fluorescence Yo/ Yo

The proposed method minimized the influence of the initial vertical background shift of reaction. The background corrected or normalized fluorescence data was used to calculate PCR efficiency by LinRegPCR software. The calculated PCR efficiency was used to derive fold expression of TFs gene using the following method:

Ratio $=\frac{(\text { E target })^{-\Delta C t}}{(\text { E control })^{-\Delta C t}}$

E target $=$ PCR efficiency of target gene in sample.

E control $=$ PCR efficiency of target gene in control.

$\Delta \mathrm{Ct}=(\mathrm{Ct}$ of target gene $-\mathrm{Ct}$ of reference gene).

\section{Results and Discussion}

Predicted features and functions of 10 cloned RGA genes were selected in this experiment for their expression analysis. The total RNA from each treatment was treated with DNase I enzyme to eliminate traces of genomic DNA (Plate 2). Actual confirmation of complete degradation of genomic DNA in RNA preparation was done through PCR amplification using total RNA as template. There was no amplification from the total RNA preparation indicating absence of traces of genomic DNA as contamination (Plate 3 and 4). However, elimination of contaminating genomic DNA enzymatically is very important in gene expression analysis using qRT-PCR (Chini et al., 2007). Presence of genomic DNA/genetic copies of genes seriously alter the precision of expression quantitation of genes in target tissues. Generally, 18S rRNA, EF-1, $\alpha$ actin, $\beta$ tubulin and ubiquitin (UBQ) genes are considered as 
good reference genes for any gene expression experiment (Caldana, 2007; Czechowski et al., 2004). The gene expression stability measure (M) was estimated to identify the most stable reference gene among actin (AC1), $\beta$-tubulin, $18 \mathrm{~S}$ rRNA and elongation factor-1 through qRT-PCR in a set of 3 different cDNA samples corresponding to different interval of day after flowering i.e. 7 DAI, 15 DAI and 30 DAF tissues from french bean leaves inoculated with rust (where inoculated samples were collected from both resistant and susceptible genotypes at different intervals). The NormFinder software which uses modelbased variance estimation approach was used; the $M$ value should be <1.5. The $M$ value, $0.298,0.311$ and 0.326 for actin (AC1), $18 S$ rRNA and $\beta$-tubulin respectively, based on $\mathrm{M}$ value actin (AC1) gene was selected as endogenous reference gene for rest of qRTPCR experiments.

In several instances these gene has been tested and used as reference genes in qRT-PCR experiments, and the $\mathrm{M}$ values of these reports are within the range of present experimental results (Claus et al., 2004; Ruth et al., 2008; Kakar et al., 2008). It is the most stable combination indicating the absence of significant differences in the expression levels of reference genes in varied experimental conditions. In several instances of plant gene expression analysis by qRT-PCR these genes with similar combination have been adopted (Marino et al., 2003).

PCR efficiency correction was used to calculate the fold change expression in the relative quantification of gene expression. The PCR efficiency of selected genes was calculated from the exponential phase of individual amplification plot using the equation $(1+\mathrm{E})=10^{\text {slope }}$ (Ramakers et al., 2003). Subsequently, the average PCR efficiencies were computed for each individual primer pairs across all analyzed samples. The range of PCR efficiency determined was in consistent with the results reported by Kakar et al., (2008), Caldana et al., (2007) and Czechowski et al., (2004). Further, PCR efficiency was used to calculate final fold change of selected genes. The deltadelta Ct method (Livak and Schmittgen, 2001) was used to determine relative expression ratio of 27 genes (fold change). The delta-delta mathematical model of determining fold changes in the expression of genes is widely adopted in qRT-PCR (Czechowski et al., 2004; Buchanan et al., 2005; Caldana et al., 2007; Yang et al., 2010). In this method an amplification efficiency of each gene specific primer pairs from the log slope of fluorescence versus cycle number in the exponential phase and the same is used to calculate fold expression using the delta-delta Ct method. Similarly, Caldana et al., (2007) and Yang et al., (2010) used delta-delta Ct method to calculate relative fold change in rice and common bean respectively.

The technical precision of qRT-PCR was assessed by performing replicated measurements in separate PCR runs. The same pool of cDNA to account the precision in technique employed and two different pools of cDNA obtained independently from two different batches of total RNA under same condition to test precision of biological responses of plant to different day after inoculation were used. Precision, as reflected by the correlation coefficient, was high in both cases; technical and biological replicates recorded correlation coefficient values greater than 0.970 and 0.968 in different day after inoculation tissues indicating high precision of Melting curve analyses was performed for all PCR products to confirm the occurrence of specific amplification peaks and the absence of primer-dimer formation. Melting curve analysis showed that all 10 genes were giving specific amplification and there was absence of primer-dimer formation. 
Table.1 Specific primer pair sequences of french bean RGAs analyzed in response to MYMV disease manifestation using qRT-PCR

\begin{tabular}{|c|c|c|c|c|c|c|}
\hline $\begin{array}{l}\text { Sl. } \\
\text { no. }\end{array}$ & Primer name & Primer sequence (5'-3') & $\begin{array}{l}\text { Lengt } \\
\text { h (bp) }\end{array}$ & $\begin{array}{l}\text { Tm } \\
\left({ }^{\circ} \mathbf{C}\right)\end{array}$ & $\begin{array}{l}\text { GC } \\
(\%)\end{array}$ & $\begin{array}{l}\text { Produc } \\
\text { t size } \\
\text { (bp) }\end{array}$ \\
\hline \multirow[t]{2}{*}{1} & COHFBRGA1_F & ATGCAGGCCTCTGCAGTC & 18 & 60.1 & 61.1 & \multirow[t]{2}{*}{163} \\
\hline & COHFBRGA1_R & ACCTCGCGAATGCATCTA & 18 & 57.9 & 50.0 & \\
\hline \multirow[t]{2}{*}{2} & COHFBRGA2_F & GAGTCAGTGAGCGAGGAAGC & 20 & 60.3 & 60.0 & \multirow[t]{2}{*}{263} \\
\hline & COHFBRGA2_R & AGCTTGGCGTAATCATGGTC & 20 & 60.1 & 50.0 & \\
\hline \multirow[t]{2}{*}{3} & COHFBRGA3_F & ACCATGATTACGCCAAGCTC & 20 & 60.1 & 50.0 & \multirow[t]{2}{*}{245} \\
\hline & COHFBRGA3_R & CAGCAGCAGAAGCACAACTC & 20 & 59.9 & 55.0 & \\
\hline \multirow[t]{2}{*}{4} & COHFBRGA4_F & CAGGCGACGTCGAGATCTAT & 20 & 60.4 & 55.0 & \multirow[t]{2}{*}{162} \\
\hline & COHFBRGA4_R & GTGCTGCAAGGCGATTAAGT & 20 & 60.4 & 50.0 & \\
\hline \multirow[t]{2}{*}{5} & COHFBRGA9_F & GAGTCAGTGAGCGAGGAAGC & 20 & 60.3 & 60.0 & \multirow[t]{2}{*}{263} \\
\hline & COHFBRGA9_R & AGCTTGGCGTAATCATGGTC & 20 & 60.1 & 50.0 & \\
\hline \multirow[t]{2}{*}{6} & COHFBRGA25_F & GTCGAGGAAATGGCCAAA & 18 & 59.6 & 50.0 & \multirow[t]{2}{*}{154} \\
\hline & COHFBRGA25_R & CACAGTCCCAGCAGCAGA & 18 & 59.7 & 61.1 & \\
\hline \multirow[t]{2}{*}{7} & COHFBRGA26_F & CGAGGAAATGGCCAAAAGTA & 20 & 60.1 & 45.0 & \multirow[t]{2}{*}{179} \\
\hline & COHFBRGA26_R & CGCTGGAAGAAGAGAAATGC & 20 & 60.1 & 50.0 & \\
\hline \multirow[t]{2}{*}{8} & COHFBRGA27_F & CGAGGAAATGGCCAAAAGTA & 20 & 60.1 & 45.0 & \multirow[t]{2}{*}{179} \\
\hline & COHFBRGA27_R & CGCTGGAAGAAGAGAAATGC & 20 & 60.1 & 50.0 & \\
\hline \multirow[t]{2}{*}{9} & COHFBRGA32_F & CTCCGCCTAGGAGTGAGTTG & 20 & 60.0 & 60.0 & \multirow[t]{2}{*}{217} \\
\hline & COHFBRGA32_R & GCCGTGCCTAAAGACTGAAC & 20 & 59.9 & 55.0 & \\
\hline \multirow[t]{2}{*}{10} & COHFBRGA38_F & AACGTCGTGACTGGGAAAAC & 20 & 60.0 & 50.0 & \multirow[t]{2}{*}{145} \\
\hline & COHFBRGA38_R & AATTTCCATTCGCCATTCAG & 20 & 59.9 & 40.0 & \\
\hline
\end{tabular}


Table.2 Relative change in the expression pattern of selected $\mathrm{R}$ genes found in MYMV manifested leaf tissue at 7, 15 and 30 DAI in french bean

\begin{tabular}{|c|c|c|c|c|c|c|c|c|c|c|c|c|c|c|c|c|}
\hline \multirow[t]{2}{*}{ Sl. No. } & \multirow[t]{2}{*}{ Genes } & \multicolumn{3}{|c|}{ Normalize $\Delta \mathrm{Ct}$ values (control) } & \multicolumn{3}{|c|}{ Normalize $\Delta \mathrm{Ct}$ values } & \multicolumn{3}{|c|}{ Fold expression } & \multicolumn{3}{|c|}{ Log10 ratio } & \multicolumn{3}{|c|}{ Cal. $t$ value } \\
\hline & & 7DAI & 15DAI & 30DAI & 7DAI & 15DAI & 30DAI & 7DAI & 15DAI & 30DAI & 7DAI & 15DAI & 30DAI & 7DAI & 15DAI & 30DAI \\
\hline 1 & RGA1 & 1.939 & 12.588 & 12.629 & 12.927 & 12.629 & 2.040 & 0.010 & 0.005 & 4.139 & -2.002 & -2.308 & 0.617 & 0.397 & 0.343 & 0.169 \\
\hline 2 & RGA2 & 6.276 & 4.960 & 4.089 & 5.500 & 4.089 & -1.404 & 110.268 & 82.983 & 76.283 & 2.042 & 1.919 & 1.882 & 0.401 & 0.347 & 0.171 \\
\hline 3 & RGA3 & 12.285 & 10.464 & 4.850 & 10.462 & 4.850 & 1.002 & 0.559 & 41.897 & 86.366 & -0.253 & 1.622 & 1.936 & 0.405 & 0.351 & 0.172 \\
\hline 4 & RGA4 & 9.623 & 10.238 & 7.434 & -24.446 & 7.434 & 9.837 & 40.534 & 0.795 & 0.031 & 7.131 & -0.099 & -1.514 & 0.411 & 0.356 & 0.174 \\
\hline 5 & RGA5 & -0.756 & 7.104 & 4.809 & 7.889 & 4.809 & 1.349 & 0.025 & 6.880 & 0.734 & -1.600 & 0.838 & -0.134 & 0.363 & 0.363 & 0.363 \\
\hline 6 & RGA6 & 2.575 & 7.591 & 0.902 & 2.661 & 0.902 & 0.272 & 20.634 & 121.312 & 26.367 & 1.315 & 2.084 & 1.421 & 0.374 & 0.374 & 0.374 \\
\hline 7 & RGA7 & 7.028 & 7.825 & 4.993 & 8.231 & 4.993 & 3.817 & 0.048 & 0.553 & 0.423 & -1.322 & -0.257 & -0.374 & 0.391 & 0.391 & 0.391 \\
\hline 8 & RGA8 & 3.841 & 4.138 & 2.576 & 4.028 & 2.576 & -4.409 & 5.048 & 3.915 & 88.851 & 0.703 & 0.593 & 2.949 & 0.423 & 0.423 & 0.423 \\
\hline 9 & RGA9 & 6.363 & 4.545 & 5.386 & 4.886 & 5.386 & 0.959 & 0.972 & 0.976 & 5.851 & -0.013 & -0.010 & 0.767 & 0.568 & 0.599 & 0.568 \\
\hline 10 & RGA10 & 4.844 & 5.351 & 3.508 & 5.722 & 3.508 & 6.240 & 38.116 & 68.619 & 79.239 & 7.581 & 8.248 & 7.425 & 0.675 & 0.565 & 0.357 \\
\hline
\end{tabular}

DAI: Days after inoculation

$\Delta \mathrm{Ct}$ : Normalized $\mathrm{Ct}$ value $\quad \Delta \mathrm{Ct}$ : (Ct of target gene-Ct of reference gene)

Table t value $(1 \%$, df: 3$)=5.8409$

Fig.1 Relative change in the expression pattern of selected RGA genes found in rust manifested leaf tissue at 15 and 30 days after inoculation of resistant and susceptible genotypes in french bean

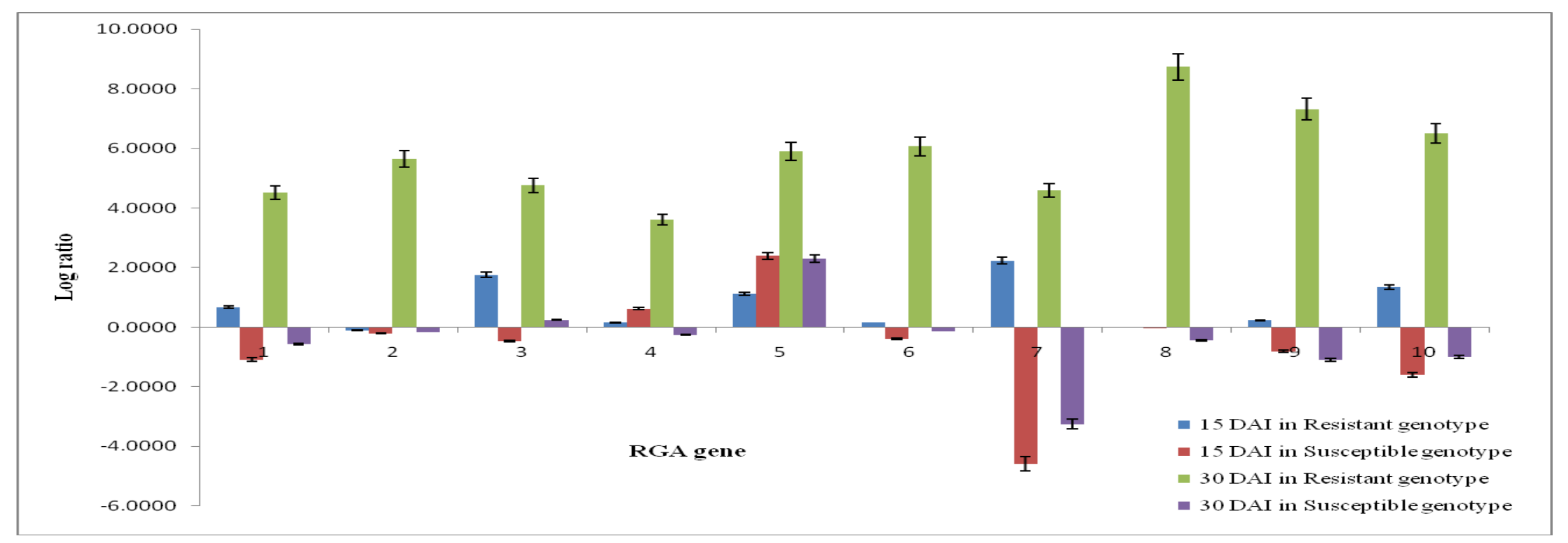


Fig.1a Technical precision of real time PCR reflected as correlation coefficient between the duplicate measurements of cDNA levels of genes from the same reverse transcription reaction (biological replicates)

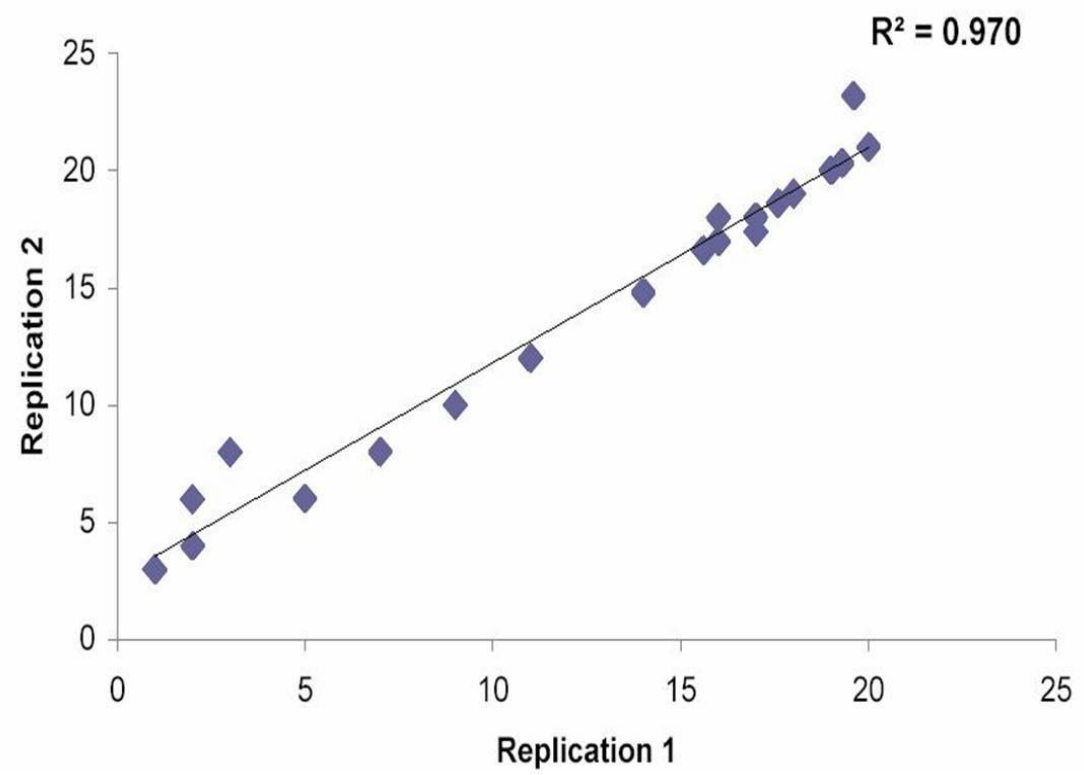

Fig.1b Technical precision of real time PCR reflected as correlation coefficient between the duplicate measurements of cDNA levels of genes from the same reverse transcription reaction (technical replicates)

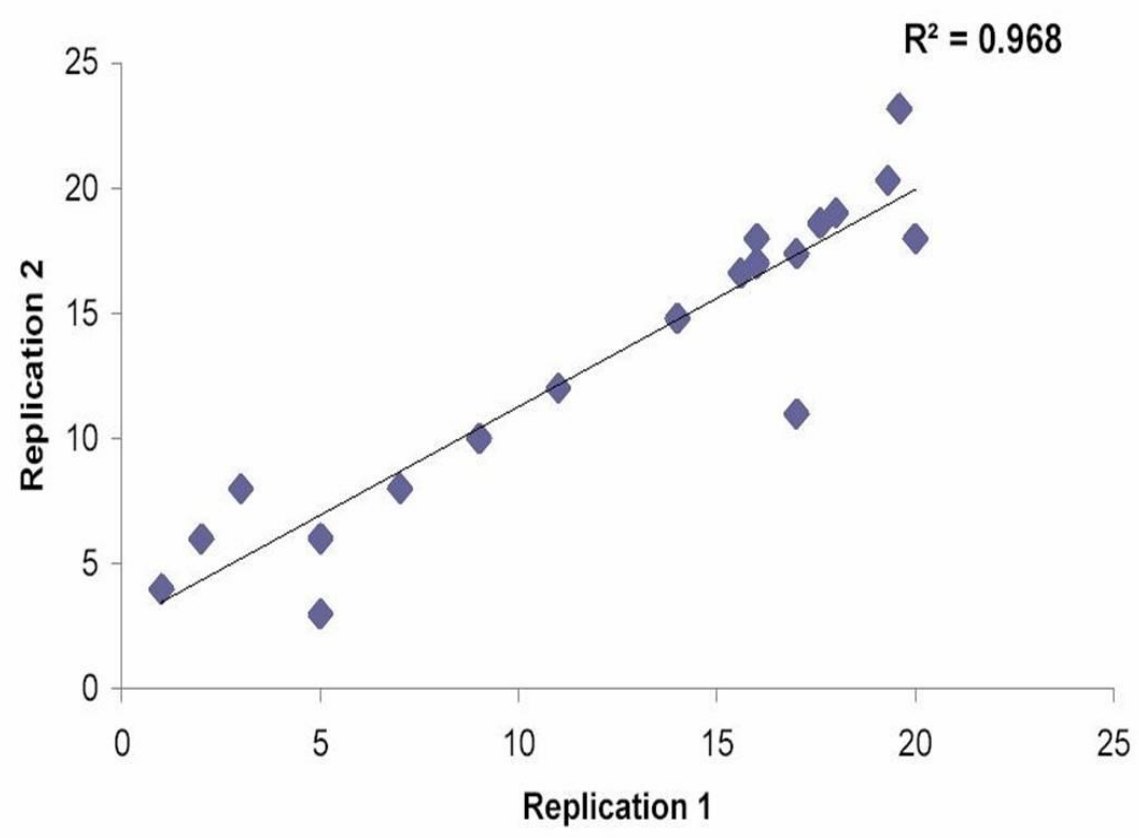




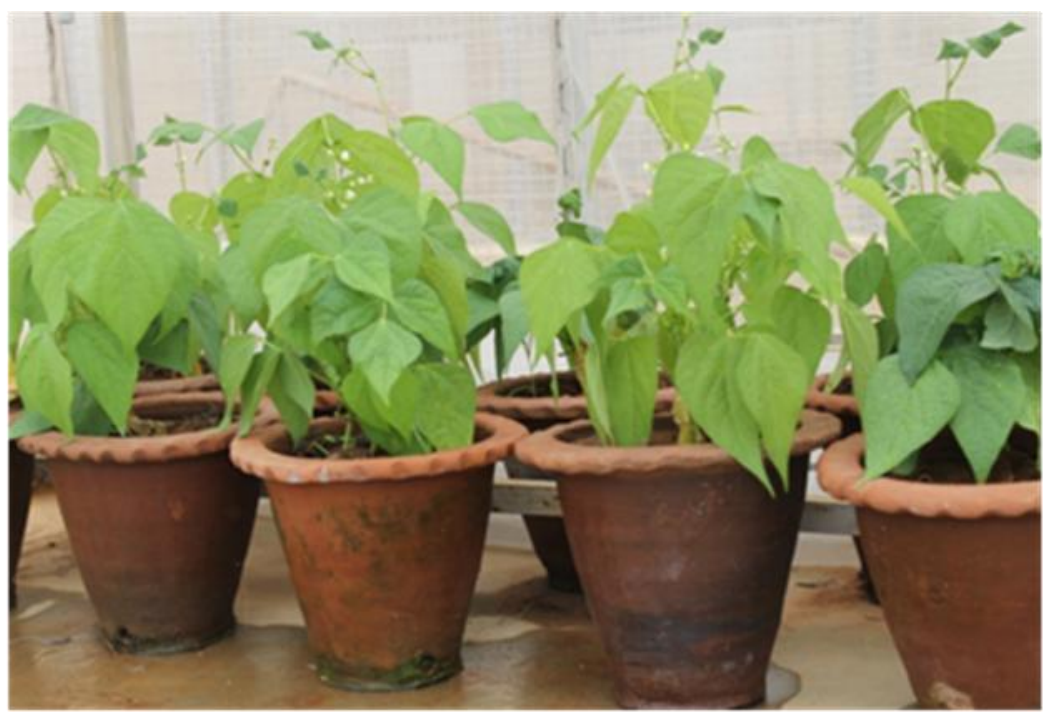

Plate la: With out disease inoculation of $M Y M V$

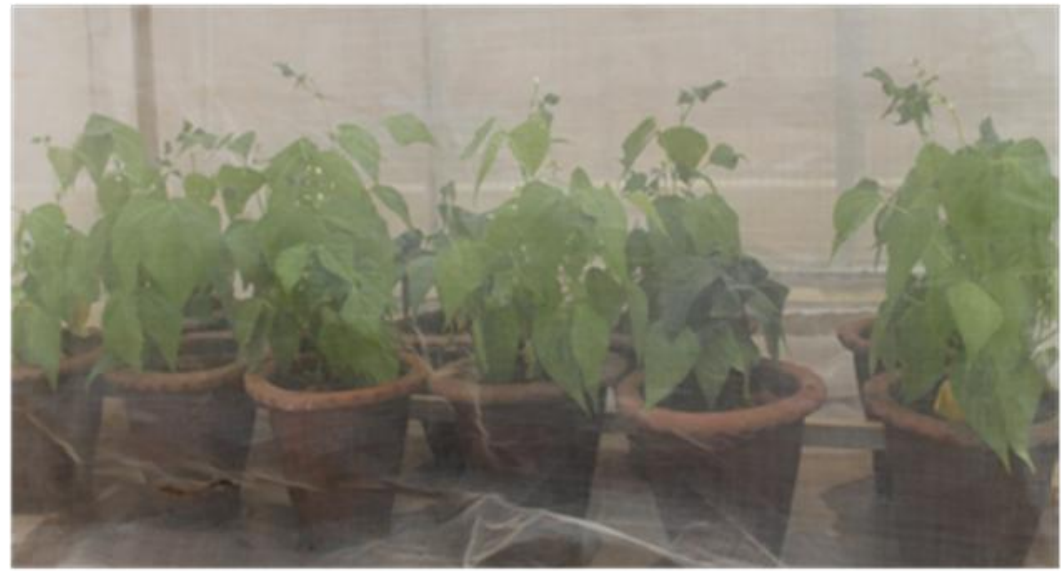

Plate 1b: Inoculation with $M Y M V$

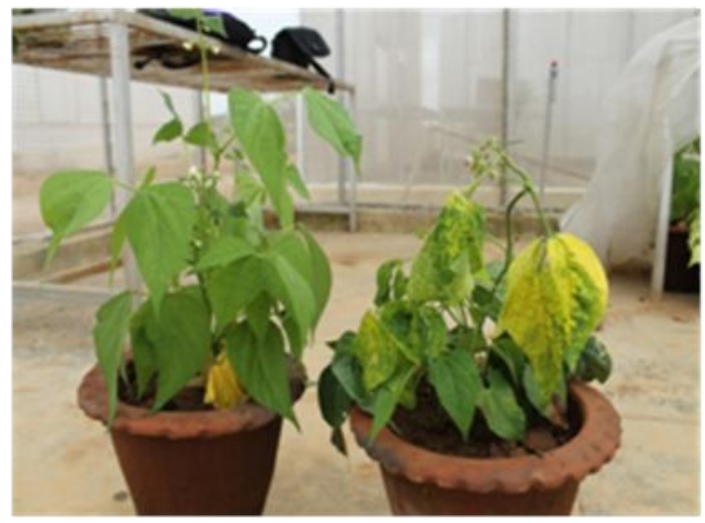

Plate 1c: Disease free and infected plant showing $M Y M V$ symptom 30DAI

Plate 1: Gener al view of pot culture for $M Y M V$ infected tissues collection 


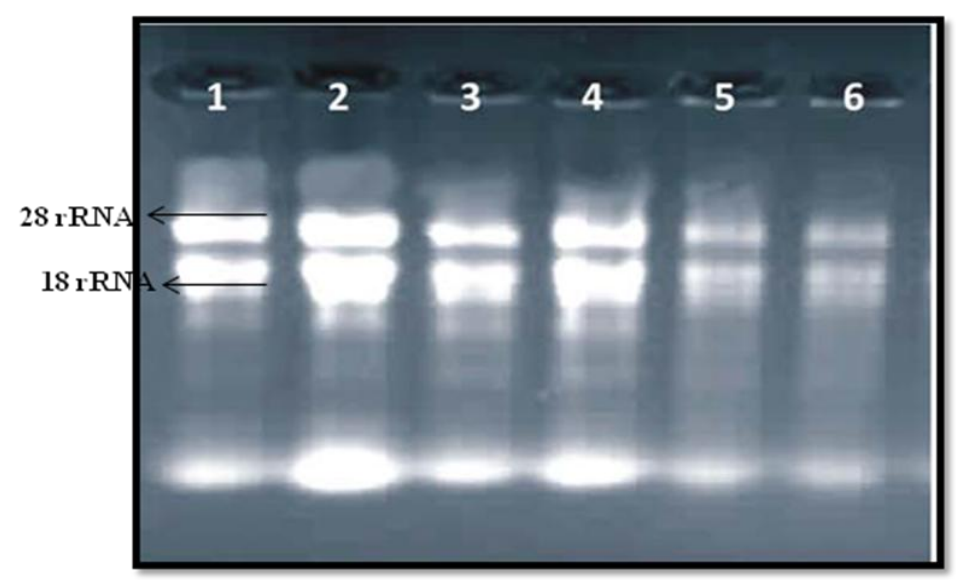

1-3-TOTAL RNA samples of rust infected leaf

4-6-TOTAL RNA samples of $M Y M V$ infected leaf

Plate 2: Confirmation of integrity and quality of total RNA on formaldehyde den aturing agar ose gel

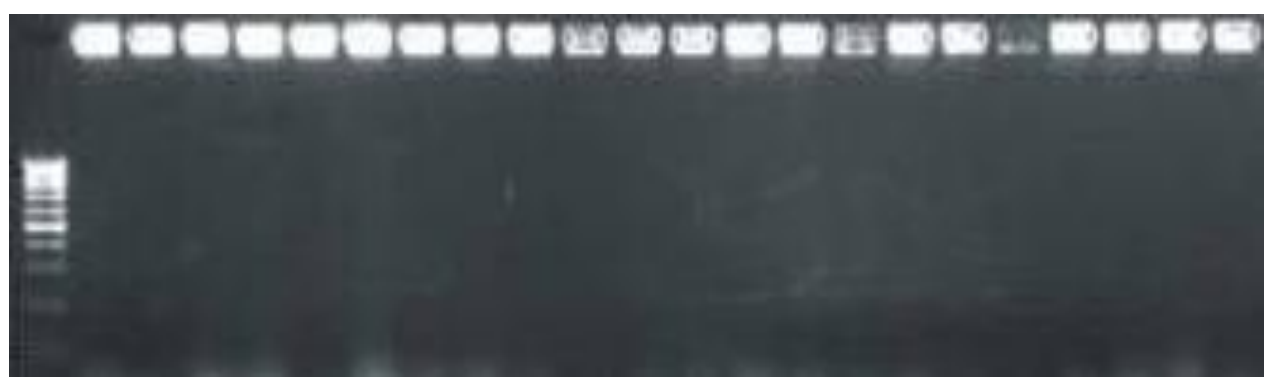

M: 100 bp ladder

1-22:MYMV infected leaf samples

Plate 3: PCR confirmation of pridicted genes with total RNA for complete degradation of genomic traces upon Dnase 1 treatment

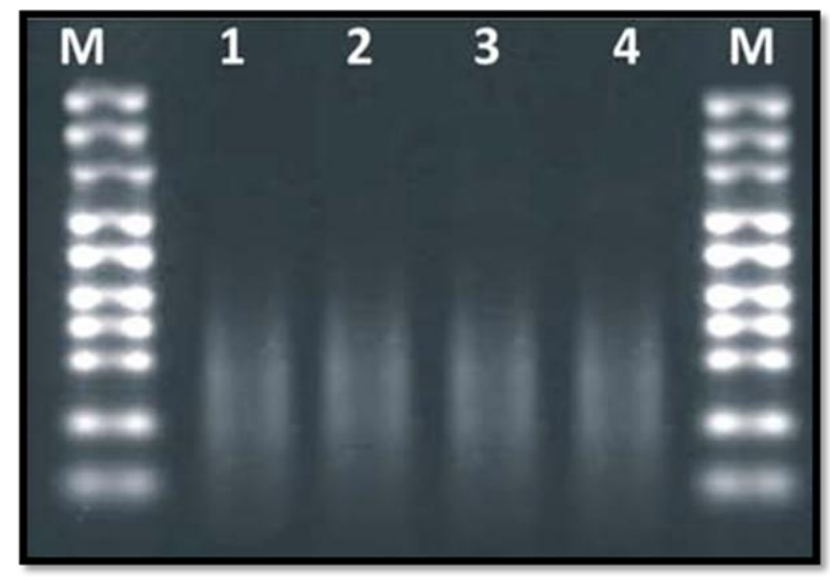

M: 1000 bp ladder

Plate $4 \mathrm{cDNA}$ from differ ent stage of $M Y M V$ infected leaf sample on $1.2 \mathrm{per}$ cent agarose 
Similar technical and biological precision in drought stress experiments leading to qRTPCR testing of RGA gene was reported in Arabidopsis (Liu et al., 2007; Huang et al., 2008; Seo et al., 2009), soyabean (StolfMoreira et al., 2010) and maize (Li technical and biological treatments and response of french bean tissues (Figure 1a and 1b). A similar strategy to monitor the technical and biological precision of experiment was adopted by Czechowski et al., (2004) in Arabidopsis thaliana and by Kakar et al., (2008) in Medicago and Wang, 2007; Xiaofeng et al., 2009).

10 RGA genes were tested under MYMV infested condition in french bean (Table 1). All 10 selected RGA genes were expressed in leaf tissues at different days after inoculation with MYMV. COHFBRGA-2, 25, 27 and 38 genes of french bean were up-regulated in leaf of susceptible genotypes at disease inoculation condition at all the intervals with a fold change ranged between 5.048 to 110.268 (7 DAI), 3.915 to 121.312 (15 DAI) and 26.367 to $88.851 \quad(30 \quad$ DAI $)$. COHFBRGA-26 was down- regulated among all the intervals of disease development in susceptible genotype with highest fold change of 0.553 at 15 DAI and range was 0.048 to 0.423. At 7 and 15 DAI, COHFBRGA-1 was down-regulated with 0.01 to 4.139 range of fold expression and it was up-regulated at 30 DAI (0.005). Down-regulation of COHFBRGA-3 was observed at 7 DAI with 0.559 fold change and it was inversely expressed at both 15 and 30 DAI 41.897 and 86.366 fold changes was observed for both intervals. Whereas, in case of COHFBRGA-4 down-regulation exhibited for 15 and $30 \mathrm{DAI}$ with fold change of 0.795 and 0.031 respectively, but was up-regulated at 7 DAI with 40.534 fold expressions. Downregulation at 7 and $30 \mathrm{DAI}$ and up-regulation at 15 DAI was notice for COHFBRGA-32 with fold change ranged between 0.025 to
6.88. But COHFBRGA-9 did not get expressed in 7 and 15 DAI and expressed only at 30 DAI with 5.851 fold change (Table 2 and Figure 1).

Emediato et al., (2013) revealed that, gene expression for RGAs in both compatible and incompatible interactions across the infection time course with Mycosphaerella musicola in banana showed low levels of RGA expression in the early infection stages and up-regulation in late stages. In contrast, other RGAs displayed high expression levels in the resistant cultivar during the early infection stage, strong down-regulation in the intermediate infection stage, and recovery to higher levels in the final stages of the infection time course. Wang et al., (2006) reported that differences in transcript levels could be correlated with the reaction to susceptibility/resistance of the host plant to pathogen. Gao et al., (2006) found that some RGAs were expressed only after challenge with Verticillium dahlia in cotton.

In conclusion, this study strongly suggests that in common bean Assessing expression of RGAs in other tissues apart from leaf tissue at two time points to gain deeper understanding of these genes in manifestation of other disease.

\section{References}

Anonymous.2015. Statistical data on horticulture crops in Karnataka state. Department of Horticulture. Government of Karnataka. Lalbagh. Bangalore.

Arumuganatham, K. and Earle, E. D.1991. Nuclear DNA content of some important plant species. Plant. Mol. Boil. Rept., 9: 208-218.

Buchanan, C. D., Lim, S., Salzman, R. A., Kagiampakis, I., Morishige, D. T., Weers, B. D., Klein, R. R., Pratt, L. H., Cordonnier-Pratt, M. M., Klein, P. E. and Mullet, J. E.. 2005. Sorghum bicolor 
transcriptome response to dehydration, high salinity and ABA. Pl. Mol. Bio., 58: 699-720.

Caldana, C., Scheible, W. R., Mueller-Roeber, B. and Ruzicic, S., 2007, A quantitative RT PCR platform for high-throughput expression profiling of 2500 rice transcription factors. Pl. Meth., 3: 17461748.

Chini, V., Foka, A., Dimitracopoulos, G. and Spiliopoulou. 2007. Absolute and relative real time PCR in the quantitation of tst gene expression among methicillin resistant Staphylococcus aureus: Evaluation by two mathematical models. Soc. App. Microbiol., 45: 479-484.

Claus, A. L., Jens, J. L. and Torben, O. F. 2004. Normalization of real-time quantitative reverse transcription-PCR data: A modelbased variance estimation approach to identify genes suited for normalization, applied to bladder and colon cancer data sets. Cancer Res., 64: 5245-5250.

Coyne, D. P. and Schuster, M. L. 1975. Genetic and breeding strategy for resistance to rust (Uromyces phaseoli Reben Wint.) in beans (Phaseolus vulgaris L.). Euphytica, 24: 795-803.

Czechowski, T., Bari, R. P., Stitt, M., Scheible, W. R. and Udvardi, M. K. 2004. Real time PCR profiling of over 1400 Arabidopsis transcription factors: unprecedented sensitivity reveals novel root and shoot specific genes. $\mathrm{Pl}$. J., 38: 366-379.

Emediato, F. L., Passos, M. A. N., Teixeira, D. C. C., Pappas, G. J. and Miller, R. N. G. 2013. Analysis of Expression of NBS LRR resistance gene analogs in Musa acuminata during compatible and incompatible interactions with Mycosphaerella musicola. Acta Hort., 986: 255-258.

Flor, H. H. 1956. The complementary genic system in flax and fax rust. Adv. Genet., 8: 29-54.

Gao, Y. L., Guo, W. Z., Wang, L. and Zhang, T. Z. 2006. Isolation and characterization of resistance and defense gene analogs in cotton (Gossypium barbadense L.). Life Sci., 49:530-542.

Harter, L. L. and Zaumeyer, W. J. 1941. Differentiation of physiological races of Uromyces phaseoli typica on bean. J. Agric. Res, 62: 717-731.

Huang, D., Wu, W., ABRAMS, S., R. and Cutler, A., J. 2008. The relationship of drought related gene expression in Arabidopsis thaliana to hormonal and environmental factors. J. Exp. Bot., 59(11): 2991-3007.

Kakar, K., Wandrey, M., Czechowski, T., Gaertner, T., Scheible, W. R., Stitt, S., Torres-JEREZ, I., Xiao, X., Redman, J. C., Wu, H. C., Cheung, F., Town, C. D. and Udvardi, M. K. 2008. A community resource for high throughput quantitative RT PCR analysis of transcription factor gene expression in Medicago truncatula. Pl. Meth, 4: 18-23.

Kalpan., 1981. What is the origin of the common bean? Econ. Bot., 35: 240-254.

Li, H. Y. and Wang, T. Y. 2007. Isolation and characterization of induced genes under drought stress at the flowering stage in maize. DNA Seq., 18(6): 445-460.

Liebenberg, M. M. and Pretorius, Z. A.2010. Common Bean Rust: Pathology and Control. Horticultural Reviews, 37: 1-74.

Liu, C., Zhou, J., Bracha-Drori, K., Yalovsky, S., Ito, T. and YU, H. 2007. Specification of Arabidopsis floral meristem identity by repression of flowering time genes. Develop., 134: 1901-1910.

Livak, K. J. and Schmittgen, T. D. 2001. Analysis of relative gene expression data using real time quantitative PCR and the 2-DDCT method. Pl. Meth., 25: 402-408.

Lopez, C. E., Acosta, I. F., Jara, C., Pedraza, F., Gaitan-Solis, E., Gallego, G., Beebe, S. and Tohme, J. 2003. Identifying resistance gene analogs associated with resistance to different pathogens in common bean. Phytopathol., 93: 88-95.

Mackay, I. M., Arden, K. E. and Nitsche, A. 2002. Real time PCR in virology. Nucl. Acids Res., 30: 1292-1305.

Marino, H. J., Cook, P. and Miller, K. S.2003. 
Accurate and statistically verified quantification of relative mRNA abundances using SYBR Green I and realtime RT-PCR. J. Immunol. Meth., 283: 291-306.

Mohan, N., Aghora, T. S., and Girija, G.1993. Sources of resistance to rust (Uromyces phaseoli) in french bean. In: Golden Jubilee Symposium Horticultural Research changing Scenario, May 24-28, 1993. Bangalore, Karnataka, India.

Prajapati, N. D.2003. A hand book of medicinal plants: A complete source book. Agrobios. Jhodhpur. 538, 539 and 390.

Ramakers, C., Ruitjer, J. M., Deprez, R. H. and Moorman, A. F.2003. Assumption free analysis of quantitative real time polymerase chain reaction (PCR) data. Neurosci. Let., 13: 62-66.

Rangaswamy, G.1975. Diseases of Crop Pants in India (2nd edn.), Prentice Hall of India Pvt., Ltd., New Delhi, pp. 250.

Ruth, C., Martin, V. G., Hollenbeck, T., James, E. and Dombrowski, G., 2008, Evaluation of reference genes for quantitative RTPCR in Lolium perenne. Crop Sci., 48: 1881- 1887.

Seo, P. J., Xiang, F., Qiao, M., Park, J. Y., Lee, Y. N., Kim, S. G., Lee, Y. H., Park, W. J. and Park, C. M., 2009, The MYB96 transcription factor mediates abscisic acid signaling during drought stress response in Arabidopsis. Pl. Physiol., 151: 275289.
Stolf-Moreira, R., Lemos, E. G. M., CararetoAlves, L., Marcondes, J., Pereira, S. S., Rolla, A. A. P., Pereira, R. M., Neumaier, N., Binneck, E., Abdelnoor, R. V., Oliveira, M. C. N., Marcelino, F. C., Farias, J. R. B. and Nepomuceno, A. L.2010. Transcriptional profiles of roots of different soybean genotypes subjected to drought stress. Pl. Mol. Bio. Rep., 56: 234-241.

Wang, X., El Hadrami, A., Adam, L. R. and Daayf, F.2006. Local and distal gene expression of pr-1 and PR-5 in potato leaves inoculated with isolates from the old (US-1) and the new (US-8) genotypes of Phytophthora infestans (Mont.). Environ. Exp. Bot., 57:70-79.

Xiao-Feng, D., Feng-Ling, F. and Wan-Chen, L, I. 2009 Differential gene expression in response to drought stress in maize seedling. Agril. Sci., 8(7): 767- 776.

Yang, S. S., Valdés-López, O., Xu, W. W., Bucciarelli1, B., Gronwald, J. W., Hernández G. and Vancel, C. P.2010. Transcript profiling of common bean (Phaseolus vulgaris L.) using the gene chip soybean genome array: Optimizing analysis by masking biased probes. $B M C$ Pl. Biol., 10: 1-58.

Yu, A., Geng, H. and Zhou, X.2006. Quantify single nucleotide polymorphism (SNP) ratio in pooled DNA based on normalized fluorescence real time PCR. $B M C$ Genom., 7: 143-153.

\section{How to cite this article:}

Divya, B., B. Fakrudin and Ashwat, C. 2019. Expression Profiling of Resistance Gene Analogs from French Bean (Phaseolus vulgaris L.) for the Manifestation of Moong Bean Yellow Mosaic Virus. Int.J.Curr.Microbiol.App.Sci. 8(03): 596-608. doi: https://doi.org/10.20546/ijcmas.2019.803.073 